\title{
Responses of young cucumber plants to root and shoot temperatures
}

\author{
A. Kleinendorst and B. W. Veen \\ Centre for Agrobiological Research (CABO), Wageningen, Netherlands
}

Received 23 March 1982; accepted 28 July 1982

Key-words: cucumber, development, growth analysis, root temperature, shoot temperature

\section{Summary}

Young cucumber plants were grown at all combinations of three shoot and three root temperatures $\left(12,18\right.$ and $\left.24^{\circ} \mathrm{C}\right)$. Growth and development of vegetative parts and fruits were studied after a temperature treatment of 14 days or 28 days. It is concluded that shoot temperature has a positive effect on rate of leaf development; the rate of leaf initiation is influenced to a minor degree. There is only a small effect of root temperature on the rate of leaf appearance.

The number of fruits is increased with increasing shoot and root temperature, the shoot temperature being more important than the root temperature. The total fruit fresh weight also increases with increasing shoot temperature; at $24^{\circ} \mathrm{C}$ shoot temperature, however, the fruit weight shows an optimum at $18{ }^{\circ} \mathrm{C}$ root temperature. At $24^{\circ} \mathrm{C}$ shoot temperature, however, the influence of root temperature on the number of leaves differs from that on the number of fruits; the lower the root temperature, the more fruits present at a given leaf number. Distribution of dry matter is also dependent on root temperature and to a greater extent on shoot temperature. A shoot temperature of $18{ }^{\circ} \mathrm{C}$ is optimal for root growth, $24{ }^{\circ} \mathrm{C}$ shoot or root temperature is still sub-optimal for shoot growth. Increase in shoot temperature has a stronger positive effect on stem growth than on leaf dry weight. The relative effect of root temperature on stem growth equals that on leaf growth.

Growth analysis shows that increase in relative growth rate (RGR) at higher shoot and root temperatures under low light conditions is achieved by increasing the specific leaf area (SLA) of the plants, in other words, the leaves become thinner at higher temperature. This adaptation to changes in shoot or root temperature occurs within 14 days.

Cultivars showing the highest SLA at the desired temperature seem to be the best qualified to give optimal RGR at low light intensities prevailing in early spring.

\section{Introduction}

In early spring high prices are paid for fresh fruits and vegetables. Growers of fruits and vegetables such as tomatoes, strawberries, lettuce and cucumbers try to im- 
prove the climatic conditions in their glasshouses in early spring to harvest as early as possible. Cucumbers are planted under low light conditions, and growth and development is stimulated by increasing the air temperature.

The effect of air heating on plant growth can be twofold. Directly, the air temperature affects the activity of the shoot, indirectly rising air temperature increases soil and root temperature, which can also have a beneficial effect on growth and development of the plant.

Experiments of Kleinendorst \& Brouwer $(1970,1972)$ demonstrated different temperature optima for the root, the shoot and the top meristem of maize. Increase in air temperature proceeds at the expense of much energy: the glass roof is badly insulated, and a small part of the heat is released to the soil. If air temperature, empirically considered as optimal, partly exercises its effect by increasing root temperature, direct heating of the soil could save much energy.

The aim of the experiment was to study the separate effects of root and shoot temperature on development and growth of cucumber, growing under low light intensity.

\section{Materials and methods}

For the experiments two $F_{1}$ hybride cultivars of cucumber (Cucumis sativus $\mathrm{L}$.) were used, Farbio and Sandra. The seeds were sown in moist sand in a climate room at $20{ }^{\circ} \mathrm{C}, 75 \%$ relative humidity and a daylength of 8 hours. The light intensity was about $30 \mathrm{~W} \mathrm{~m}^{-2}$.

After 9 days, when the plants were about $5 \mathrm{~cm}$ high, a number of uniform plants were selected and placed in 1-litre pots with Hoagland nutrient solution. For the experiments plants of two ages were used: stage I plants which were grown for 11 days on a nutrient solution at $20^{\circ} \mathrm{C}$ and stage II, plants which had the same pre-treatment during 20 days.

A number of consecutive experiments were carried out in a climate room at an air temperature of 12,18 or $24{ }^{\circ} \mathrm{C}$. Relative humidity was $75 \%$, light intensity $30 \mathrm{~W}$ $\mathrm{m}^{-2}$ (wavelength $400-700 \mathrm{~nm}$ ), and daylength 8 hours. Three root temperatures, 12 , 18 and $24{ }^{\circ} \mathrm{C}$, were realized at each air temperature by placing the pots with nutrient solution in a cooled or heated water bath of constant temperature. The nutrient solution was renewed every two days with solution of the desired root temperature. At the beginning of each experiment four plants of both cultivars were harvested and another four plants of each growing condition were harvested 14 days and 28 days after the beginning of the experiment. The plants were harvested during the last 3 hours of the light period. Fresh and dry weight of different plant parts and the surface area of the different leaves were measured.

The vegetative development of a plant is characterized by the plastochron index (PI; Erickson \& Michelini, 1957). This numerical index is based on the number of leaves that have attained an arbitrary reference length or surface area. In this case a reference surface area of $5 \mathrm{~cm}^{2}$ was chosen. A plant is considered to be $n$ plastochrons old, when leaf $n$ has just attained a surface of $5 \mathrm{~cm}^{2}$, and $(n+1)$ plastochrons old, when leaf $(n+1)$ has reached this surface area. When leaf $n$ is larger than $5 \mathrm{~cm}^{2}$ 
and leaf $(n+1)$ smaller than $5 \mathrm{~cm}^{2}$, PI is found by interpolation between $n$ and $(n+$ 1). The increase in plastochron index per unit of time is called the rate of leaf appearance.

A second parameter by which the development of the plants is characterized is the rate of fruit initiation. Only fruits longer than $1 \mathrm{~cm}$ were used. Because the size of the plants at the end of the pre-treatment period of each experiment was not exactly the same, the influence of the different temperature treatments on a number of plant parameters was expressed as a relative value with respect to the situation at the end of the pre-treatment period.

Unless mentioned otherwise the influence of a change in root temperature is shown as the average effect at the three shoot temperatures and the effect of shoot temperature as the average of the three root temperatures. This was done only when no interaction was observed between the effects of shoot and root temperature.

Only when different temperature effects on cv. Sandra and cv. Farbio were observed, are the effects shown separately, otherwise the average effect is shown.

\section{Results}

\section{Rate of leaf development}

At equal shoot and root temperature of $18{ }^{\circ} \mathrm{C}$ the PI increases exponentially. Fig. 1 shows a distinctly positive effect of increasing shoot temperature on the rate of leaf appearance during the first 14 days after temperature change, but the second 14 days the differences between 18 and $24{ }^{\circ} \mathrm{C}$ have almost disappeared, which can be

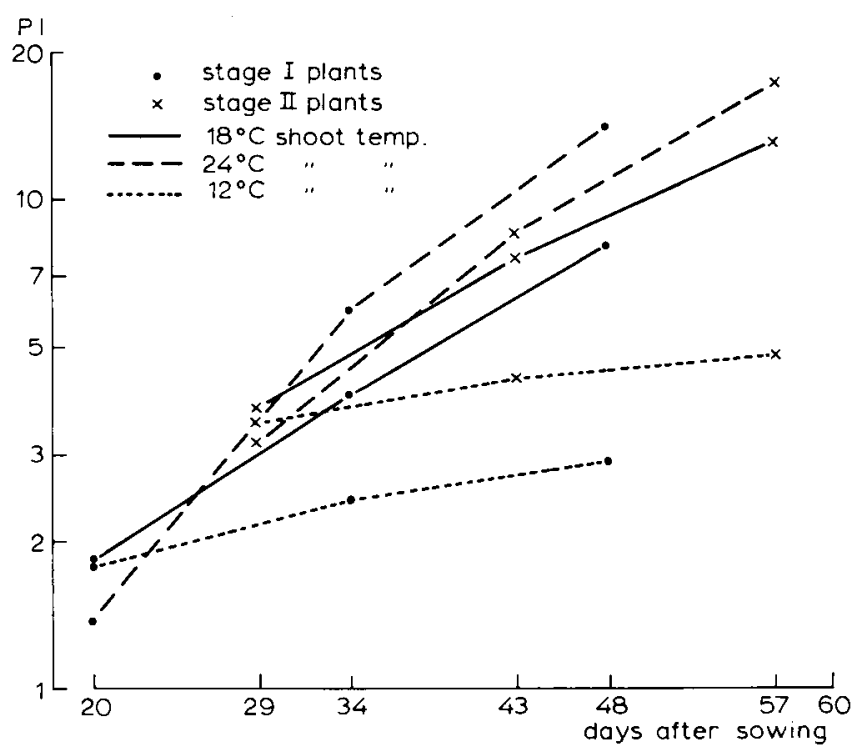

Fig. 1. Influence of shoot temperature on the PI at $18{ }^{\circ} \mathrm{C}$ root temperature of stage I and stage II plants. 


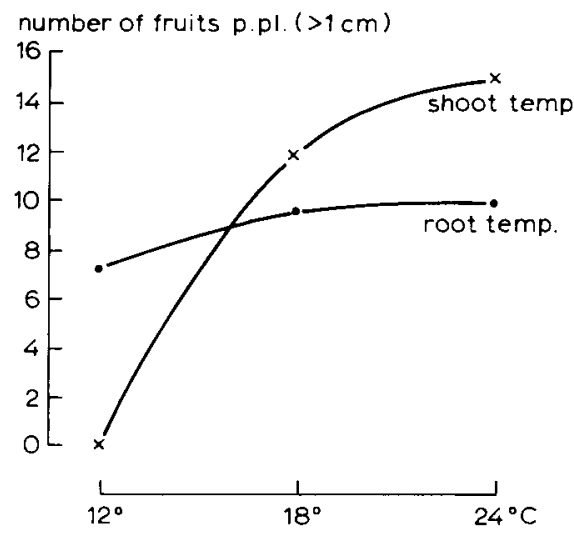

Fig. 2. Influence of shoot and root temperature on the number of fruits $(>1 \mathrm{~cm})$ per plant. Stage II plants after 28 days.

considered as an adaptation of the plant to a change in temperature. The rate of leaf appearance during the first 14 days at $12{ }^{\circ} \mathrm{C}$ was delayed compared with $18{ }^{\circ} \mathrm{C}$ shoot temperature. In the second 14 days at $12^{\circ} \mathrm{C}$ shoot temperature no adaptation of the rate of leaf appearance was observed, possibly due to reduced chlorophyl replacement at this low shoot temperature. In comparison with shoot temperature, the effect of root temperature on the PI was only small.

\section{Rate of fruit development}

At the respective harvests only fruits were present on stage II plants after 14 days and 28 days at $24{ }^{\circ} \mathrm{C}$ shoot temperature, and after 28 days at $18{ }^{\circ} \mathrm{C}$. Stage I plants only had fruits after 28 days at $24{ }^{\circ} \mathrm{C}$ shoot temperature, so that the effect of shoot and root temperature on fruit number could only be demonstrated on stage II plants after an experimental period of 28 days (Fig. 2). The number of fruits is closely dependent on the shoot temperature. The effect of root temperature is much smaller.

At $24{ }^{\circ} \mathrm{C}$ shoot temperature the relation between number of fruits and the PI is influenced by the root temperature (Fig. 3). The higher the root temperature the fewer fruits present at a given PI.

\section{Growth analysis}

In the experiments the effects were also studied of shoot and root temperature on the relative growth rate ( $R G R, \mathrm{mg} \mathrm{g}^{-1} \mathrm{day}^{-1}$ ). The RGR at different shoot and root temperatures is shown in Fig. $4 a$ and $4 b$. The effect of shoot temperature was much greater than the effect of root temperature. The RGR decreased with increasing plant age, so stage II plants had a lower RGR than stage I plants. The first 14 days of the experiments the RGR of cv. Sandra was greater than that of cv. Farbio, the second 14 days the difference had disappeared.

The influence of shoot and root temperature on plant growth was twofold: a temperature influence on dry matter production and an effect of temperature on partitioning of dry matter between the different parts of the plant.

The influence of root and shoot temperature on the relative dry weight of shoot 


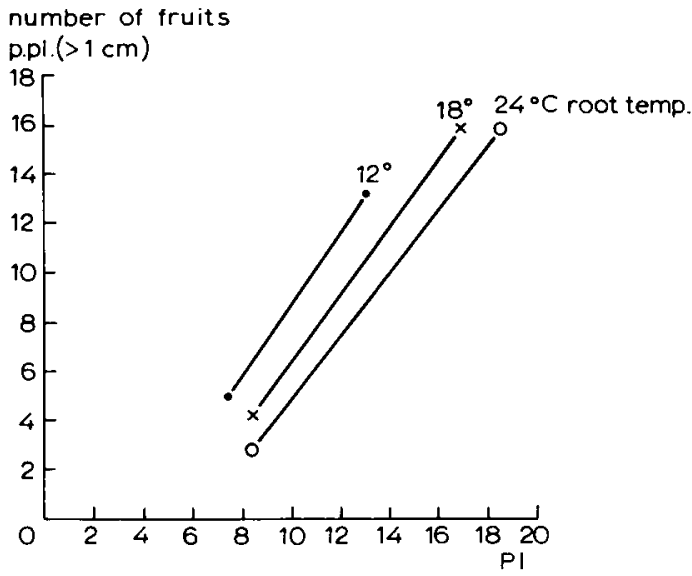

Fig. 3. Relation between PI and the number of fruits $(>1 \mathrm{~cm})$ per plant at 12,18 and $24{ }^{\circ} \mathrm{C}$ root temperature at a shoot temperature of $24^{\circ} \mathrm{C}$.

and root is shown in Fig. 5a and 5b. Increase in shoot and root temperature both have a positive effect on shoot dry weight (Fig. 5a), increase in shoot temperature being more effective than increase in root temperature.

The effect of shoot and root temperature on root growth showed an optimum at about $18{ }^{\circ} \mathrm{C}$. Shoot temperature had a greater effect on root growth than root temperature (Fig. 5b). Summarizing it can be said that the shoot/root ratio increased at increasing shoot and root temperature.
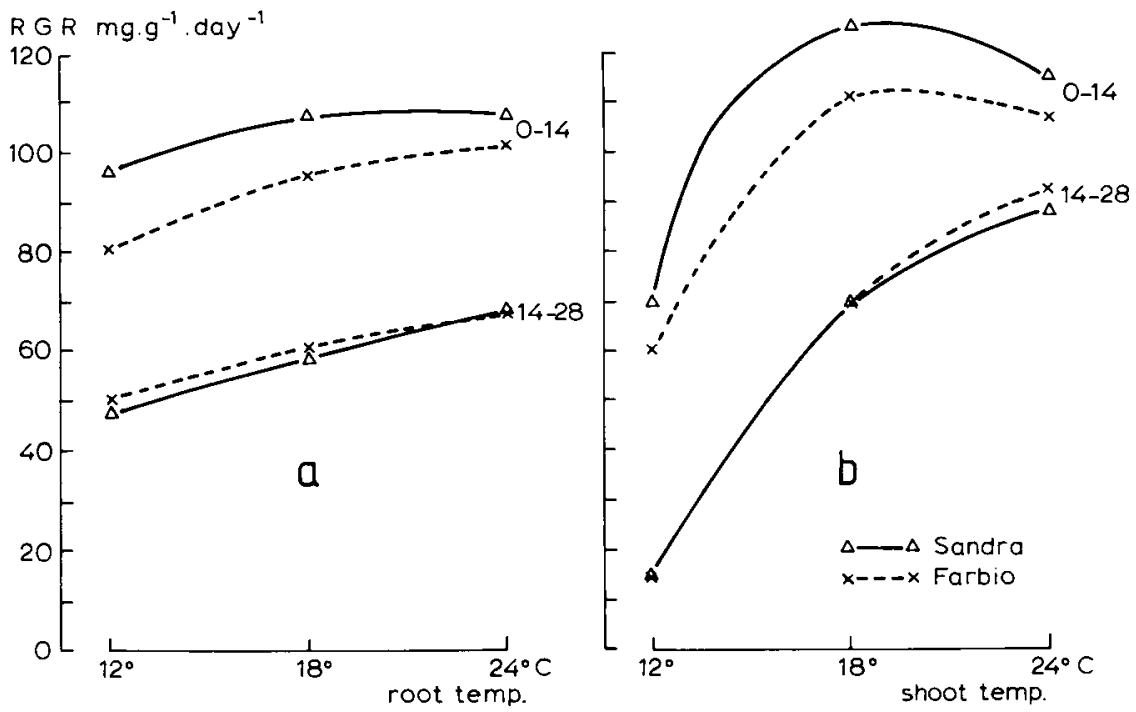

Fig. 4. The influence of root (a) and shoot (b) temperature on the average RGR of the total plant dry weight ( $\mathrm{mg} \mathrm{g}^{-1}$ day $^{-1}$ ) of $\mathrm{cv}$. Sandra and cv. Farbio during 0-14 days and 14-28 days. 

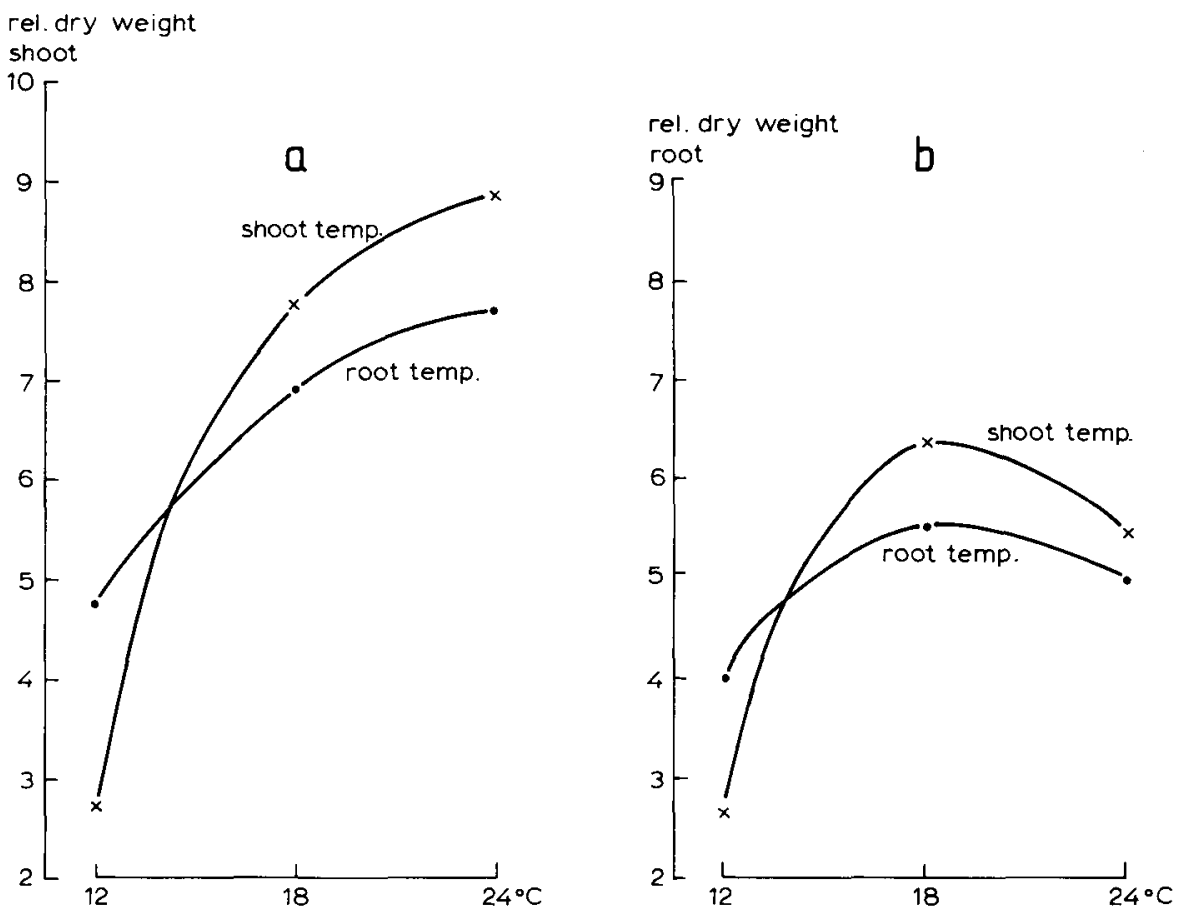

Fig. 5. Influence of shoot and root temperature on the relative dry weight of shoot (a) and root (b).

In addition to the influence on shoot/root ratio, shoot temperature affected partitioning of dry matter between leaf and stem tissue (Fig. 6). At higher shoot temperature the stem/leaf ratio was increased. The stem/leaf ratio was not influenced by increase in root temperature, both parts were stimulated to the same extent.

The amount of dry weight invested in leaves in relation to the total dry weight of the plant is called the leaf weight ratio (LWR, $\mathrm{g} \mathrm{g}^{-1}$ ). Besides the leaf dry weight, the leaf area per unit leaf dry weight is an important factor determining the photosynthetic capacity of the plant. This parameter is called the specific leaf area (SLA, $\mathrm{cm}^{2} \mathrm{~g}^{-1}$ ). The SLA increased sharply with increasing shoot temperature and to a much lesser degree was positively affected by the root temperature (Fig. 7). The change in SLA after changing shoot or root temperature occurred during the first two weeks. In the second period of two weeks SLA stayed about the same (Fig. 8).

The product of the two plant parameters LWR and SLA is the leaf area ratio (LAR, $\mathrm{cm}^{2} \mathrm{~g}^{-1}$ ), the ratio between the total leaf surface area and the dry weight of a plant. The LAR is an important factor determining the photosynthetic capacity per unit plant weight. Both shoot and root temperatures had a positive effect on the LAR (Fig. 9). The effect of shoot temperature was greater than the effect of root temperature.

Except for the morphological parameters LWR, SLA and LAR, the RGR of a plant is also dependent on the net assimilation rate (NAR), that is the increase in 

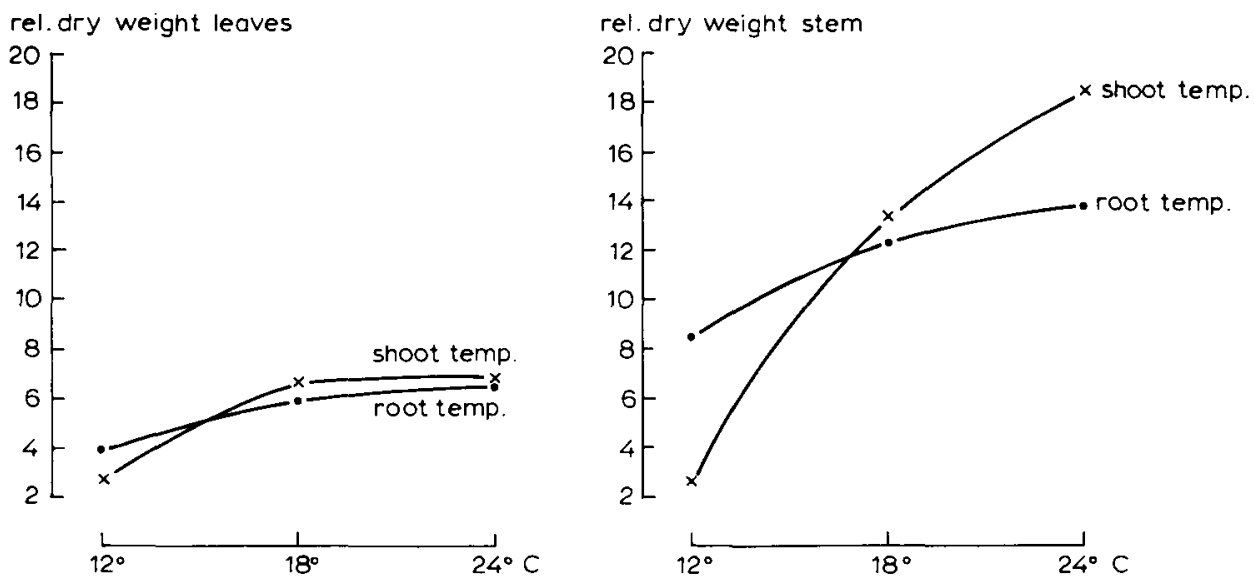

Fig. 6. Influence of shoot and root temperature on the relative dry weight of leaves and stem.

plant dry weight per unit leaf area and per unit time $\left(\mathrm{mg} \mathrm{cm}^{-2} \mathrm{day}^{-1}\right)$. The relation between RGR, LAR and NAR can be expressed as:

$$
\mathrm{RGR}=\mathrm{LAR} * \mathrm{NAR}
$$

Both RGR and NAR decreased with time (Fig. 10). In the first 14-day period the optimal NAR is at $18^{\circ} \mathrm{C}$ shoot temperature, the second 14 days the difference between $18{ }^{\circ} \mathrm{C}$ and $24{ }^{\circ} \mathrm{C}$ have almost disappeared. At $12{ }^{\circ} \mathrm{C}$ shoot temperature NAR is very low because of reduced chlorophyl replacement. Root temperature hardly influences NAR (Grobbelaar, 1963).

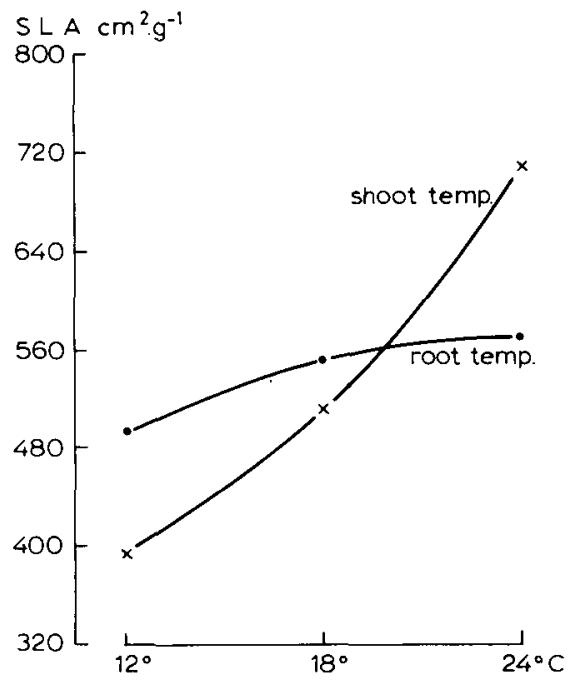

Neth. J. agric. Sci. 31 (1983)
Fig. 7. Influence of shoot and root temperature on SLA $\left(\mathrm{cm}^{2} \mathrm{~g}^{-1}\right)$. 
A. KLEINENDORST AND B. W. VEEN

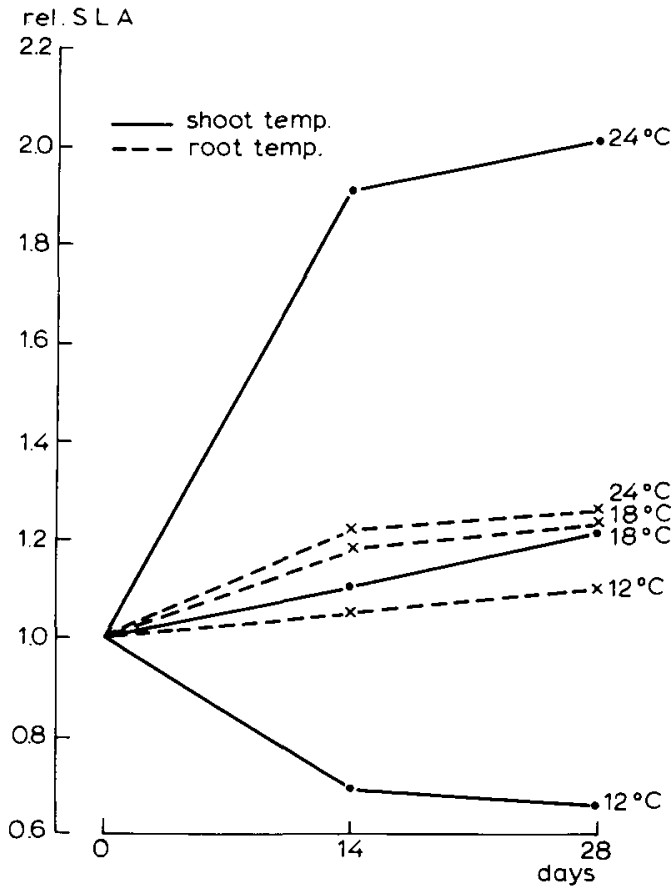

Fig. 8. Influence of shoot and root temperature on relative SLA after 0,14 and 28 days.

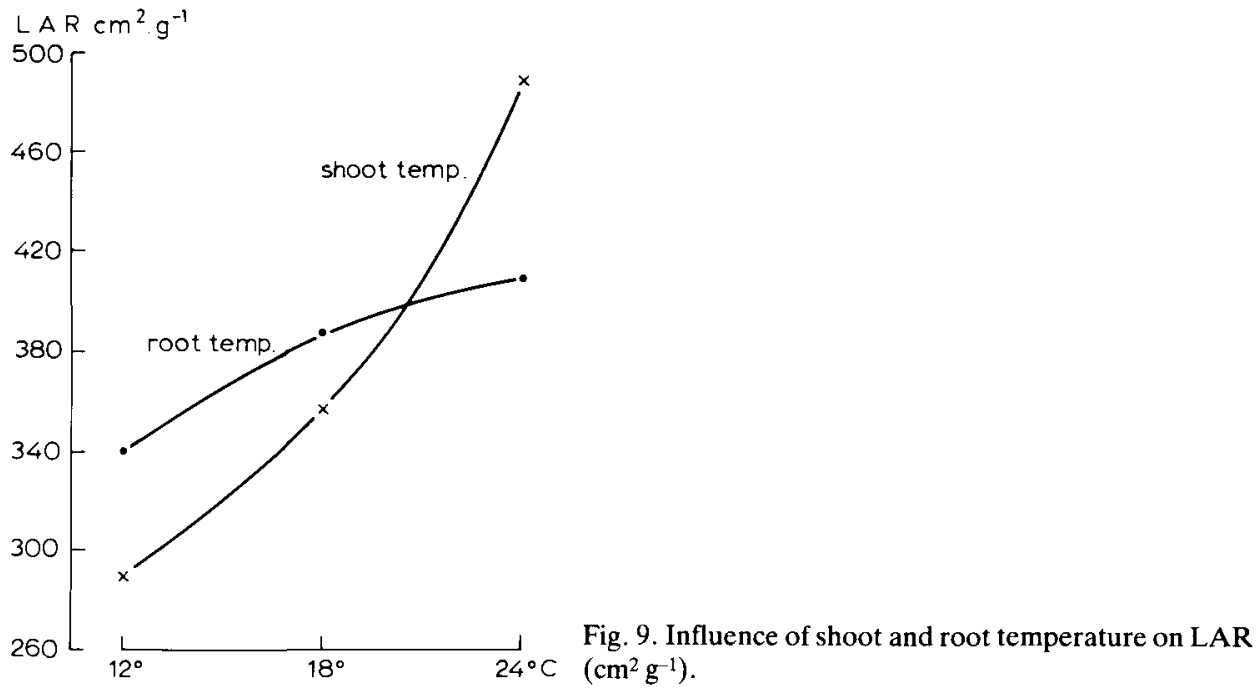




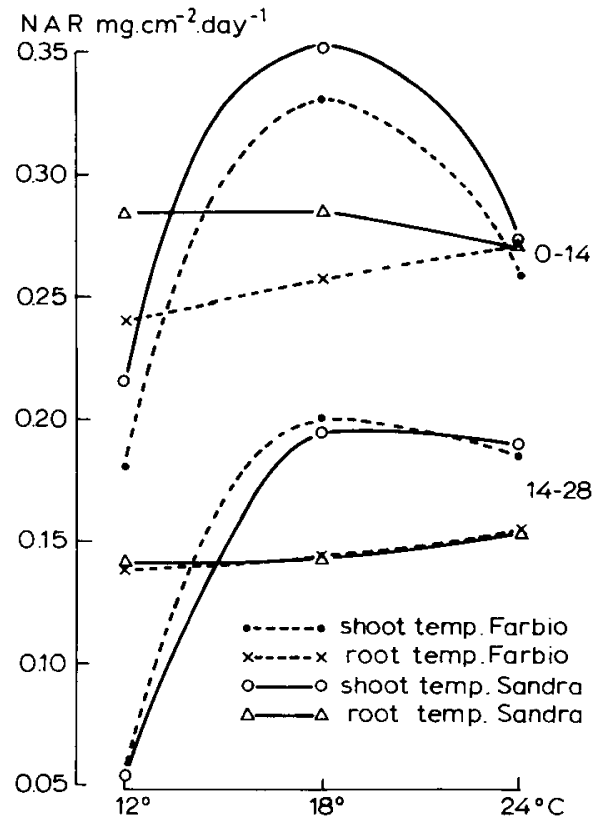

Fig. 10. The influence of shoot and root temperature on the average NAR $\left(\mathrm{mg} \mathrm{cm}^{-2} \mathrm{day}^{-1}\right)$ of $\mathrm{cv}$. Sandra and cv. Farbio during 0-14 days and 14-28 days, at stage I plants.

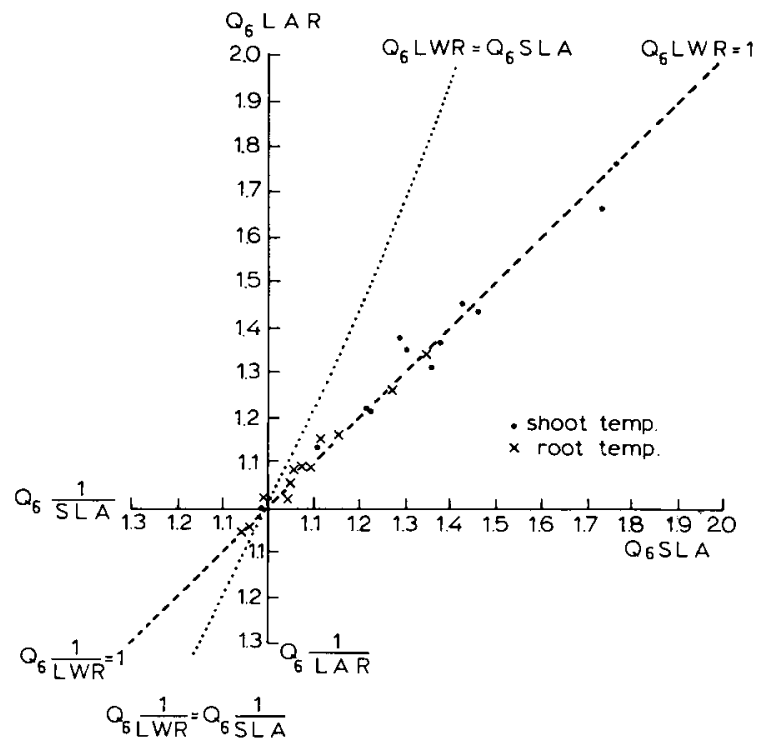

Fig. 11. Relation between the $Q_{6}$ value of SLA and the $Q_{6}$ value of $L A R$. 


\section{A. KLEINENDORST AND B. W. VEEN}
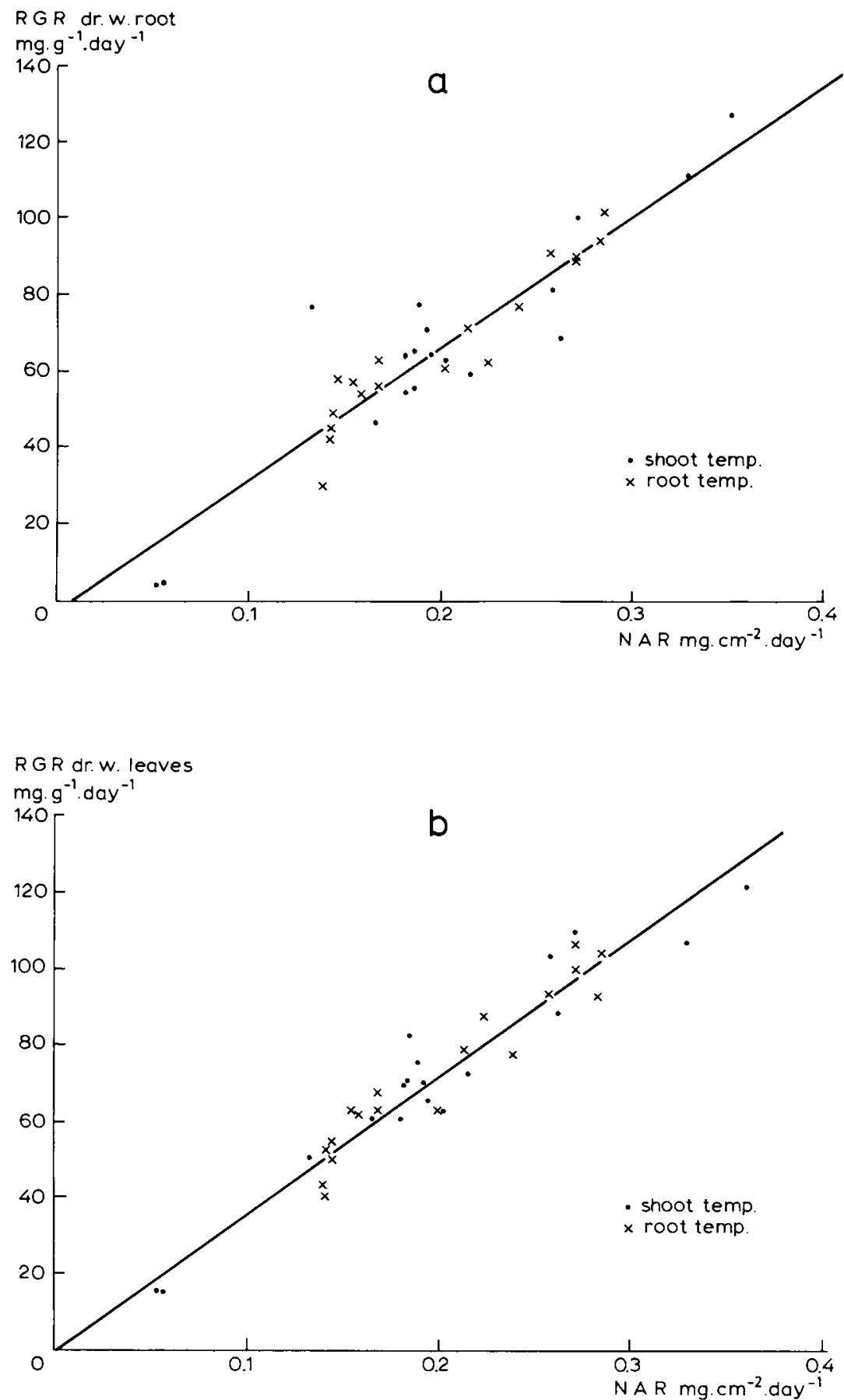


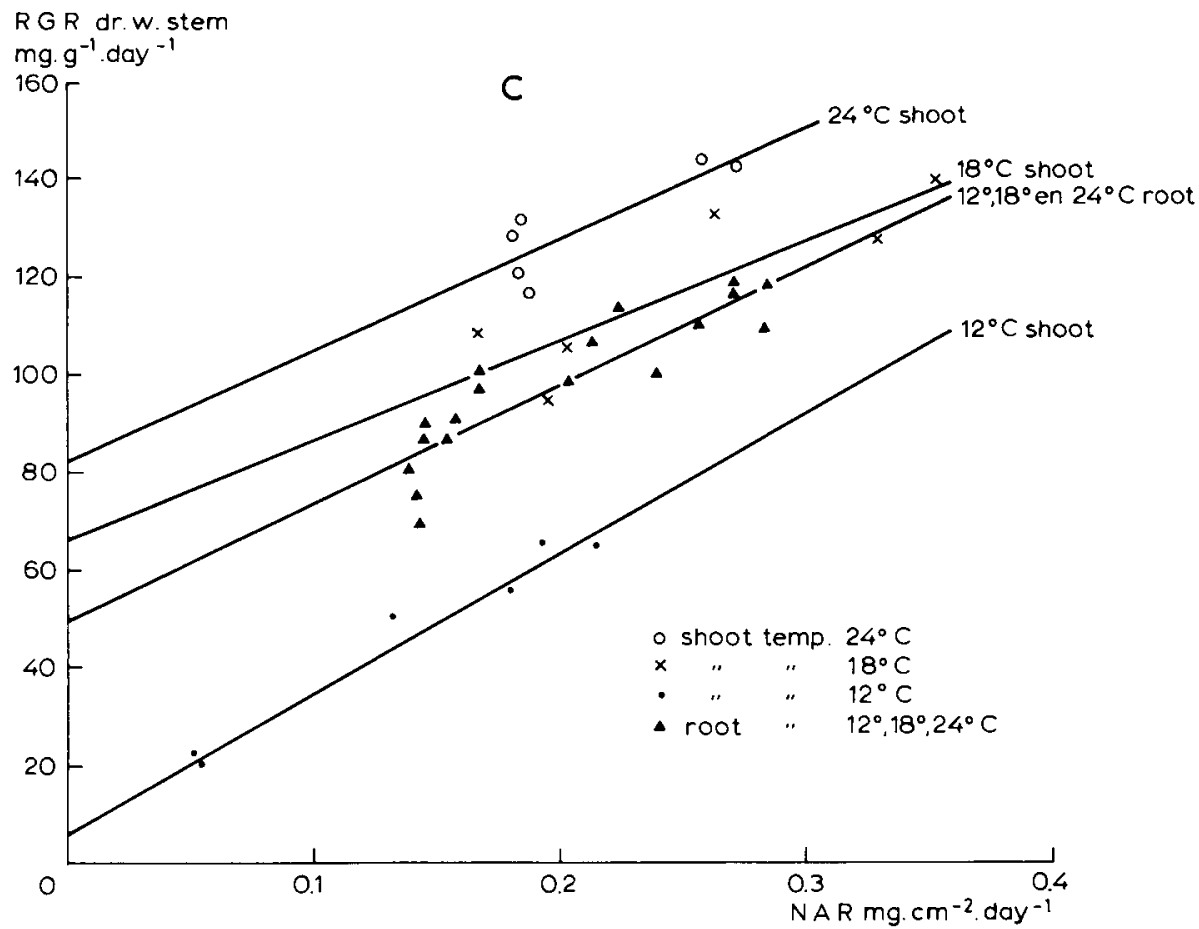

Fig. 12. The relation between NAR ( $\mathrm{mg} \mathrm{cm}^{-2}$ day $\left.^{-1}\right)$ and RGR of the dry weight $\left(\mathrm{mg} \mathrm{g}^{-1}\right.$ day $\left.^{-1}\right)$ of root (a), leaves (b) and stem (c) at different shoot and root temperatures.

Because LAR can be considered as the product of LWR and SLA and RGR as the product of LAR and NAR, the temperature influence on RGR can be regarded as the product of the effects of temperature on LWR, SLA and NAR.

Qualitative aspects of temperature, $Q_{6}$

To quantify the effect of a change in shoot or root temperature on the different plant parameters the term $\mathrm{Q}_{6}$ is introduced. $\mathrm{Q}_{6}$ can be defined as the quotient of the values of LWR, SLA, LAR, NAR or RGR estimated at two temperatures differing $6{ }^{\circ} \mathrm{C}$. Without temperature influence the $\mathrm{Q}_{6}$ is 1.00 , a positive temperature effect is characterized by $a Q_{6}>1.00$ and a negative effect results in a $Q_{6}<1.00$.

To compare the absolute temperature effects, $Q_{6}$ values $<1.00$ are expressed as the reciprocal of the $Q_{6}$ value. Fig. 11 shows a relation between the $Q_{6}$ values of LAR and SLA. Because LAR $=$ SLA $*$ LWR, the dotted line indicates an equal temperature influence on LWR and SLA and the broken line an equal effect of temperature on SLA and LAR. Fig. 11 distinctly shows that the effect of shoot and root temperature on LAR can be completely explained by a positive influence of temperature on SLA. In other words, at higher temperatures the leaves become thinner. Parallel to the effect on SLA the adaptation of LAR to a change in temperature occurs within 14 days. In Table 1 the effects of shoot and root temperatures on 
Table 1. Influence of shoot and root temperature on net assimilation rate (NAR), leaf area ratio (LAR) and relative growth rate (RGR) of cucumber expressed in $Q_{6}$ values.

\begin{tabular}{|c|c|c|c|c|c|c|c|c|c|}
\hline \multirow{3}{*}{$\begin{array}{l}\text { Temperature } \\
\left({ }^{\circ} \mathrm{C}\right)\end{array}$} & \multicolumn{6}{|c|}{ Stage I plants } & \multirow{2}{*}{\multicolumn{3}{|c|}{$\frac{\text { Stage II plants }}{0-14 \text { days }}$}} \\
\hline & \multicolumn{3}{|c|}{$0-14$ days } & \multicolumn{3}{|c|}{ 14-28 days } & & & \\
\hline & $\overline{\text { NAR }}$ & LAR & RGR & $\overline{\text { NAR }}$ & LAR & RGR & $\overline{\text { NAR }}$ & LAR & RGR \\
\hline \multicolumn{10}{|l|}{ Shoots } \\
\hline $12-18$ & 1.71 & 1.05 & 1.82 & 3.66 & 1.26 & 4.67 & 1.32 & 1.00 & 1.31 \\
\hline $18-24$ & $1.28^{-1}$ & 1.21 & $1.06^{-1}$ & $1.06^{-1}$ & 1.37 & 1.29 & $1.17^{-1}$ & 1.16 & 1.00 \\
\hline \multicolumn{10}{|l|}{ Roots } \\
\hline $12-18$ & 1.04 & 1.10 & 1.15 & 1.01 & 1.17 & 1.20 & 1.10 & 1.08 & 1.21 \\
\hline $18-24$ & 1.00 & 1.03 & 1.03 & 1.10 & 1.05 & 1.15 & 1.03 & 1.04 & 1.07 \\
\hline
\end{tabular}

NAR, LAR and RGR are expressed as $Q_{6}$ values. The positive influence of increase in shoot temperature from 12 tot $18^{\circ} \mathrm{C}$ on RGR can mainly be attributed to an increase in NAR.

Increase in shoot temperature from 18 tot $24^{\circ} \mathrm{C}$ has a positive effect on LAR in the first 14 days and an equally negative effect on NAR, resulting in no effect on RGR. The second 14 days the effect of temperature increase $\left(18\right.$ to $\left.24^{\circ} \mathrm{C}\right)$ on RGR is more pronounced, which is mainly due to an increase in LAR.

Increase in NAR has a positive effect on the RGR of the plant. This effect is however not the same for the different parts of the plant. Fig. 12a and $12 \mathrm{~b}$ show a linear relation between NAR and RGR of the roots and the leaves at different shoot and root temperatures.

The relation between the RGR of the stem and NAR, however, is dependent on the shoot temperature (Fig. 12c). The higher the shoot temperature the higher the RGR of the stem at the same NAR.

\section{Fruit production}

Because of the limited duration of the experiments the most complete information about fruit growth is available from stage II plants after 28 days of temperature treatment (Fig. 13). Total fresh weight of fruits at a certain moment is the result of fruit initiation and fruit growth. The developmental aspect of temperature is described above (Fig. 2). Fig. 13 shows that the influence of root temperature depends on shoot temperature.

Of the three shoot temperatures that were examined $24^{\circ} \mathrm{C}$ gives the highest fruit fresh weight production. At this shoot temperature $18{ }^{\circ} \mathrm{C}$ is the optimal root temperature. At $24^{\circ} \mathrm{C}$ shoot temperature the total fruit weight difference between 12 and $18{ }^{\circ} \mathrm{C}$ root temperature is achieved in Farbio by a higher weight of the individual fruits and in Sandra by the production of more fruits (Table 2).

Decrease in total fruit weight at $24{ }^{\circ} \mathrm{C}$ root temperature is caused by decrease in weight of the individual fruits. 


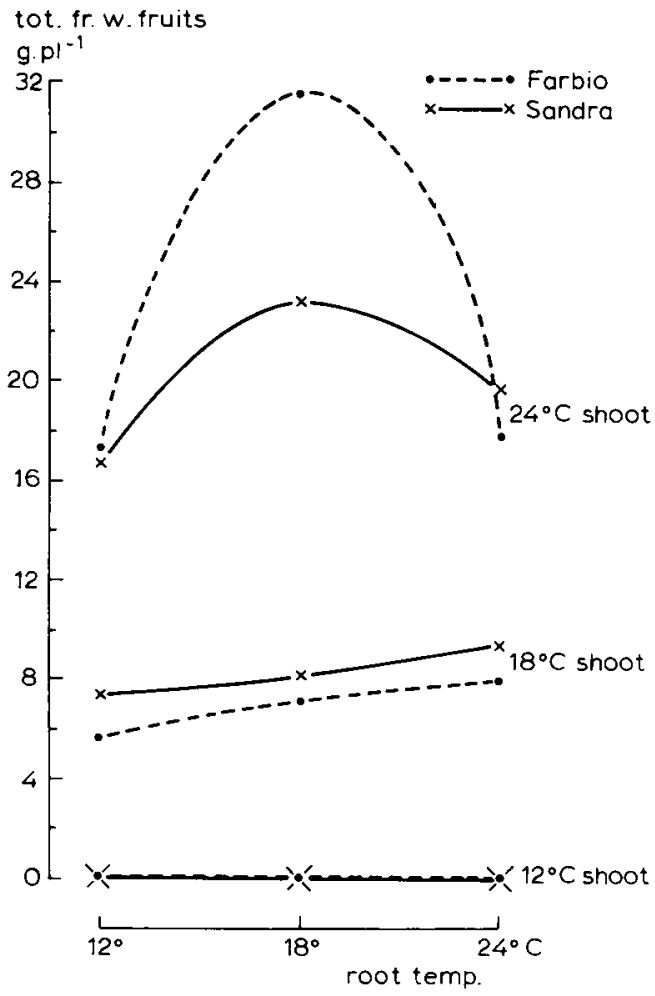

Fig. 13. Influence of root and shoot temperature on the total fresh weight of fruits ( $\mathrm{g}$ plant $^{-1}$ ) of stage II plants after 28 days temperature treatment.

\section{Discussion}

The rate of leaf appearance depends on the number of leaf primordia present and the rate of leaf development from the primordia. The number of leaf primordia depends on the initiation rate of leaf primordia and the rate of leaf appearance. If the initiation rate is faster than the rate of leaf appearance, the number of primordia increases, resulting in an increase in leaf production, until the rate of leaf appearance equals the initiation rate. The increase in rate of leaf appearance at $18{ }^{\circ} \mathrm{C}$ shoot and

Table 2. Influence of root temperature at a shoot temperature of $24{ }^{\circ} \mathrm{C}$ on the number of fruits, the average fruit fresh weight and the total fresh weight of cucumber fruits expressed in $Q_{6}$ values of stage II plants after 28 days temperature treatment.

\begin{tabular}{|c|c|c|c|c|c|c|}
\hline & \multicolumn{2}{|c|}{ Number of fruits } & \multicolumn{2}{|c|}{ Average fresh weight } & \multicolumn{2}{|c|}{ Total fresh weight } \\
\hline & $\begin{array}{l}\text { roots } \\
12-18^{\circ} \mathrm{C}\end{array}$ & $\begin{array}{l}\text { roots } \\
18-24{ }^{\circ} \mathrm{C}\end{array}$ & $\begin{array}{l}\text { roots } \\
12-18{ }^{\circ} \mathrm{C}\end{array}$ & $\begin{array}{l}\text { roots } \\
18-24{ }^{\circ} \mathrm{C}\end{array}$ & $\begin{array}{l}\text { roots } \\
12-18^{\circ} \mathrm{C}\end{array}$ & $\begin{array}{l}\text { roots } \\
18-24{ }^{\circ} \mathrm{C}\end{array}$ \\
\hline cv. Fabrio & 1.09 & 1.02 & 1.69 & $1.81^{-1}$ & 1.84 & $1.78^{-1}$ \\
\hline cv. Sandra & 1.31 & $1.01^{-1}$ & 1.05 & $1.16^{-1}$ & 1.38 & $1.18^{-1}$ \\
\hline
\end{tabular}


root temperature (Fig. 1) may occur, because in the first 60 days of development of a cucumber plant, the rate of leaf initiation exceeds that of leaf appearance, so that accumulation of leaf primordia takes place accompanied by an increase in the rate of leaf appearance. The same phenomenon was observed with lettuce (Bensink, 1971). It is suggested that the immediate increase in the rate of leaf appearance after increase in shoot temperature is caused by a direct effect of temperature on the rate of leaf development. The observation that the relative increase in rate of leaf appearance in the second period of 14 days is not influenced by increase in shoot temperature from 18 tot $24^{\circ} \mathrm{C}$ suggests that the influence of shoot temperature on leaf initiation is negligible. This is in agreement with results of Milthorpe (1956) and Bensink (1971), who showed an increase in number of leaf primordia at low shoot temperatures of cucumber and lettuce, respectively, which was attributed to a greater negative influence of low shoot temperature on leaf development than on the rate of leaf initiation.

There is only a small effect of root temperature on the initiation of leaf primordia.

Since the growth rate of a plant depends mainly on the rate of leaf area development and on the rate of dry matter production per unit leaf area, these parameters are considered as the main factors determining the growth reaction of the plant. When studying the influence of temperature on growth and development over a period of time the influence of temperature and the influence of time are mixed. Part of the influence of time and temperature is in the same direction: there is increased mutual shading of the leaves, advanced leaf senescence and decreased leaf/stem ratio. All these factors result in a decreased NAR. Besides, there is a specific temperature influence on SLA: the leaves become thinner at higher shoot and root temperatures, the influence of shoot temperature being more important than the influence of root temperature. At low light intensities decrease in leaf thickness has no effect on photosynthesis, but decreases respiration per unit leaf area (Boysen-Jensen \& Muller, 1929), so that NAR is increased.

It can be concluded that, although a primary effect of a rise in shoot temperature from 18 to $24{ }^{\circ} \mathrm{C}$ is a decrease in NAR, morphological adaptation in the first 14 days after temperature change partially compensates for this effect, so that in the second 14-day period the differences in NAR between 18 and $24^{\circ} \mathrm{C}$ have almost disappeared. At $12{ }^{\circ} \mathrm{C}$ shoot temperature NAR is very low because of reduced chlorophyl replacement.

Under low light conditions root growth is limited by carbohydrate availability (Brouwer, 1962). The low NAR at $12{ }^{\circ} \mathrm{C}$ and $24{ }^{\circ} \mathrm{C}$ shoot temperature negatively affects the carbohydrate level of the plant as compared with $18{ }^{\circ} \mathrm{C}$, which might explain the optimal effect of $18^{\circ} \mathrm{C}$ shoot temperature on root growth.

At rather low light intensities the temperature effect on SLA and LAR are most important. At higher light intensities a rise in temperature positively affects RGR mainly by stimulating NAR (Brouwer, 1973, 1974).

Increase in root temperature has only a minor effect on RGR. At the low light intensities used in these experiments light can be considered as the main limiting factor for plant growth, root activity is not rate limiting. At higher light intensities the 
influence of root temperature on plant growth is more important as is shown by Karlsen (1978) with cucumber.

At low light intensities prevailing in early spring, cultivars showing the highest SLA at the desired temperature seem to be the best qualified to give optimal RGR. Perhaps SLA can be used as a criterion for selecting cultivars for use at low light conditions.

\section{References}

Bensink, J., 1971. On morphogenesis of lettuce leaves in relation to light and temperature. Meded. Landbouwhogeschool Wageningen 71-15.

Boysen-Jensen, P. \& D. Muller, 1929. Die maximale Ausbeute und Tägliche Verlauf der Kohlensäureassimilation. Jb. wiss. Bot. 70: 493-502.

Brouwer, R., 1973. Dynamics of plant performance. Acta Hort. 32: 31-54.

Brouwer, R., 1974. A comparison of the effect of drought and low root temperatures on leaf elongation and photosynthesis in maize. Acta Hort. 39: 141-145.

Erickson, R. O. \& F. J. Micheline, 1957. The plastochron index. Am. J. Bot. 44: 297-305.

Grobbelaar, W. P., 1963. Responses of young maize plants to root temperatures. Meded. Landbouwhogeschool Wageningen 63-5.

Karlsen, P., 1978. Growth of young cucumber plants in relation to root and air temperature. Kgl. Vet. og Landbohøjsk Aarsskr. 45-52.

Kleinendorst, A. \& R. Brouwer, 1970. The effect of temperature of the root medium and of the growing point of the shoot on growth, water content and sugar content of maize leaves. Neth. J. agric. Sci. 18: $140-148$.

Kleinendorst, A. \& R. Brouwer, 1972. The effect of local cooling on growth and water content of plants. Neth. J. agric. Sci. 20: 203-217.

Milthorpe, F. L., 1956. The relative importance of the different stages of leaf growth in determining the resultant area. In: The growth of leaves. Proceedings 3rd Easter School in Agricultural Science, University of Nottingham, Butterworths, London, pp. 141-148. 